\title{
Aktivitas Minyak dan Serbuk Enam Spesies Tumbuhan terhadap Peneluran dan Mortalitas Callosobruchus sp. (Coleoptera: Bruchidae)
}

\author{
DADANG $^{1)}$, BUDI SAPUTRO $^{1)}$, DAN KANJU OHSAWA ${ }^{2)}$ \\ ${ }^{1)}$ Departemen Proteksi Tanaman, Fakultas Pertanian, Institut Pertanian Bogor \\ Jl. Kamper, Kampus Darmaga, IPB, Bogor \\ ${ }^{2)}$ Departement of Boi-Science, Faculty of Applied Bio-Science, Tokyo University of Agriculture
}

(diterima Februari 2006, disetujui Juli 2006)

\begin{abstract}
Activity of Oil and Powder of Six Plant Species against Mortality and Oviposition of Callosobruchus sp. (Coleoptera: Bruchidae). Storage pests remain one of the main problems in storage. The pest attacks occur not only in the field, but also in storage. Control should be done to maintain the quality of storedproducts. The environmentally friendly measures should be implemented to avoid negative impacts to the environment and human being. The objective of this research was to study the mortality and oviposition deterrence caused by powder and oil of six plant species against Callosobruchus sp. (Coleoptera: Bruchidae). Flowers of Eugenia aromatica, roots of Vetiveria zizanioides, leaves of Pogostemon cablin, seeds of Ricinus communis, seeds of Foeniculum vulgare, and stems of Cymbopogon citratus were air-dried and milled to yield powder. Oil of six plant species were purchased from local market. Oviposition deterrent bioassay was conducted by no-choice method for both powder and oil, while mortality bioassay was conducted by topical application and residual methods for plant oil only. Several plant species showed high biological activity to Callosobruchus sp. Powder of E. aromatica and oil of $V$. zizanioides caused high oviposition deterrence, while oil of $V$. zizanioides and $E$. aromatica caused high mortality.
\end{abstract}

KEY WORDS: Callosobruchus sp., mortality, oviposition deterrence, plant oil, plant powder

\section{PENDAHULUAN}

Di Indonesia kacang hijau (Phaseolus radiatus L.) merupakan tanaman kacang-kacangan yang penting setelah kacang kedelai (Glycine max L.) dan kacang tanah (Arachis hypogea L.). Di daerah tertentu, tanaman kacang hijau mempunyai arti ekonomi yang sangat penting dalam pemenuhan kebutuhan pangan masyarakat. Kandungan protein dan vitamin kacang hijau tidak jauh berbeda dengan kacang kedelai dan kacang tanah. Namun demikian, kandungan karbohidrat dan vitamin B kacang hijau lebih tinggi (Suprapto \& Sutarman 1982).

Produksi kacang hijau di Indonesia masih sangat rendah yaitu rata-rata $400 \mathrm{~kg}$ biji bersih per hektar. Salah satu penyebab rendahnya hasil tersebut adalah karena adanya serangan hama dan patogen tanaman. 
Kerusakan oleh hama dan penyakit tidak terbatas pada tanaman yang ada di lapangan, tetapi juga pada kacang hijau yang disimpan di gudang (Suprapto \& Sutarman 1982). Hama pascapanen yang sering menimbulkan kerusakan pada kacang hijau, baik yang akan digunakan untuk benih maupun untuk konsumsi adalah kumbang biji kacang hijau, Callosobrucbus sp. (Coleoptera: Bruchidae) (Soekarno 1977 dalam Priyono 1987).

Saat ini pengendalian hama pascapanen pada biji kacang hijau umumnya menggunakan insektisida sintetik, seperti fenitrotion, malation, metil bromida, dan paration (Tauthong \& Wanleelag 1978). Namun, penggunaan insektisida sintetik yang kurang bijaksana dapat menyebabkan efek samping seperti kematian organisme bukan sasaran, terjadinya resistensi dan resurjensi, serta adanya residu insektisida pada bahan makanan. Oleh karena itu, perlu dilakukan penelitian untuk mendapatkan alternatif pengendalian yang mampu menekan populasi hama sasaran tetapi tidak berdampak buruk pada lingkungan, serta tidak mengakibatkan kematian organisme bukan sasaran, terjadinya resistensi dan resurjensi, dan adanya residu insektisida pada bahan makanan (Rice 1983 dalam Priyono 1987).

Beberapa upaya pengendalian Callosobruchus sp. yang bersifat ramah lingkungan telah dilakukan, salah satu- nya adalah penggunaan insektisida botani. Insektisida botani biasanya diperoleh melalui metode ekstraksi untuk mendapatkan senyawa-senyawa aktif alami yang dapat menekan populasi hama sasaran. Namun bila dilihat dari aspek ekonomi, kegiatan ekstraksi ini memerlukan biaya yang cukup mahal dan kurang efisien dari segi waktu dan tenaga. Oleh karena itu, diperlukan cara lain dalam memanfaatkan senyawa-senyawa alami tersebut khususnya untuk aplikasi di lapangan.

Beberapa cara alternatif untuk mendapatkan senyawa tumbuhan telah dilakukan, salah satunya melalui metode destilasi yang produk akhirnya berupa minyak tumbuhan. Minyak ini ternyata sudah banyak tersedia di pasaran dan diperjual secara bebas. Jika dievaluasi dari aspek ekonomi, minyak tumbuhan yang diperoleh melalui metode destilasi jauh lebih murah dan efisien dibandingkan dengan metode ekstraksi menggunakan sokslet. Namun, aktivitas biologi minyak tumbuhan ini dalam menekan populasi hama sasaran masih belum banyak diteliti. Oleh karenanya perlu adanya penelitian lebih lanjut guna membandingkan efikasi minyak tumbuhan itu dengan produk ekstraksi tumbuhan dalam menekan populasi hama sasaran.

Selain minyak tumbuhan, teknik lain yang dapat digunakan untuk pengendalian hama gudang adalah 
dengan menggunakan tepung atau serbuk tumbuhan. Jika cara ini terbukti efektif maka pengendalian hama gudang akan lebih murah dan efisien dari segi waktu dan tenaga.

Penelitian ini bertujuan untuk mempelajari penghambatan peneluran Callosobruchus sp. yang diperlakukan dengan minyak dan tepung enam jenis tumbuhan dan pengaruh minyak tumbuhan terhadap mortalitas kumbang tersebut.

\section{BAHAN DAN METODE}

Penelitian dilaksanakan di Laboratorium Fisiologi dan Toksikologi Serangga, Departemen Proteksi Tanaman, Fakultas Pertanian, Institut Pertanian Bogor.

\section{Pemeliharaan Serangga Uji}

Sejumlah kumbang Callosobruchus sp. dipelihara dalam kotak plastik (15 $\mathrm{cm} \times 21 \mathrm{~cm} \times 6 \mathrm{~cm}$ ) yang telah berisi kacang hijau sebagai pakan dan media pembiakan serangga. Sebagian imago yang muncul dikumpulkan untuk digunakan dalam pengujian dan sebagian dipindahkan ke kotak plastik lain untuk perbanyakan lebih lanjut.

Imago yang digunakan adalah imago yang memiliki umur seragam. Untuk mendapatkan imago yang memiliki umur seragam dilakukan pemisahan imago ke kotak plastik lain 24 jam sebelum perlakuan. Imago yang muncul berikutnya digunakan untuk perlakuan.

\section{Bahan Tumbuhan}

Material tumbuhan, yaitu bunga Eugenia aromatica, akar Vetiveria rizanioides, daun Pogostemon cablin, biji Ricinus communis, biji Foeniculum vulgare, dan batang Cymbopogon citratus yang diperoleh di Bogor, Jawa Barat dan sekitarnya, dikering anginkan, kemudian digiling dengan menggunakan blender hingga didapatkan serbuk. Sementara itu, minyak keenam jenis tumbuhan tadi diperoleh dari pasar lokal.

\section{Pengujian Minyak Nabati}

Pengujian dilakukan dengan metode tanpa pilihan. Enam jenis minyak tumbuhan disiapkan masingmasing pada konsentrasi 0,$1 ; 0,5 ; 1 ; 3$; dan $5 \%$. Pelarut yang digunakan dalam pengujian ini adalah aseton. Sebanyak sepuluh butir biji kacang hijau direndam di dalam larutan minyak pada tiap konsentrasi selama 5-10 detik kemudian dikeringanginkan di atas alumunium foil.

Pada bagian tengah dasar cawan petri plastik dibuat lubang berdiameter $2,7 \mathrm{~cm}$ kemudian digabungkan pada leher botol plastik (diameter 2,7 cm x tinggi 3,4 cm). Dalam satu botol plastik diletakkan 10 butir kacang hijau yang telah direndam dalam larutan minyak dengan konsentrasi tertentu, sedang sebagai kontrol digunakan 10 butir kacang hijau yang direndam hanya dalam pelarut (aseton). Empat pasang imago Callosobruchus sp. dimasukkan ke dalam cawan petri 
plastik dan dibiarkan berkopulasi dan bertelur selama 3 hari. Setelah 3 hari dihitung jumlah telur yang diletakkan. Setiap perlakuan diulang 5 kali.

\section{Pengujian Serbuk Tumbuhan}

Pengujian dilakukan dengan metode tanpa pilihan. Serbuk tumbuhan diaplikasikan dengan perbandingan 1:1, 1:2, dan 1:4 (perbandingan antara bobot serbuk tumbuhan dengan bobot 10 butir kacang hijau). Metode pengujiannya dilakukan sama dengan pengujian minyak tumbuhan.

Persentase penolakan peneluran, baik oleh minyak maupun oleh serbuk tumbuhan dianalisis dengan sidik ragam dan uji lanjutan menggunakan Duncan's multiple range test pada taraf nyata 5\%. Persen penghambatan aktivitas peneluran (PAP) dihitung dengan rumus:

$$
\mathrm{PAP}=(1-\mathrm{p} / \mathrm{k}) \times 100 \%,
$$

yang $\mathrm{p}$ adalah jumlah telur pada perlakuan dan $\mathrm{k}$ adalah jumlah telur pada kontrol.

Berdasarkan persentase rata-rata penghambatan aktivitas peneluran (x), dapat ditentukan keefektivan penghambatan peneluran dengan klasifikasi sebagai berikut:

$$
\begin{array}{lr}
\text { Baik } & x \geq 80 \%, \\
\text { Cukup baik } & 60 \% \leq x<80 \%, \\
\text { Kurang baik } & x<60 \% .
\end{array}
$$

\section{Uji Mortalitas}

Metode yang digunakan dalam uji kematian ini adalah dengan perlakuan setempat (topical application) dan pengaruh residu (residual effect). Serangga uji yang digunakan ialah imago betina yang berumur kurang dari 24 jam. Imago ditetesi sediaan minyak sebanyak $1 \mu \mathrm{l} /$ serangga dengan menggunakan sonde mikro pada bagian dorsal toraks untuk tiap dosis perlakuan. Dosis yang digunakan adalah 25, 50, 100, 150, dan 200 $\mu \mathrm{g} /$ serangga. Untuk tiap perlakuan digunakan 10 ekor serangga dengan 5 kali ulangan. Pengamatan kematian serangga dilakukan pada 24, 48, dan 72 jam setelah perlakuan (JSP). Persentase kematian untuk tiap perlakuan dianalisis dengan sidik ragam dan diuji lanjutan dengan menggunakan Duncan's multiple range test pada taraf nyata 5\%. Selain itu, persentase kematian untuk tiap perlakuan dianalisis dengan analisis probit untuk menentukan hubungan dosis dan kematian serangga uji dan menentukan nilai $\mathrm{LD}_{50}$ dan $\mathrm{LD}$ 95 pada 48 JSP. Nilai $\mathrm{LD}_{50}$ dan $\mathrm{LD}_{95}$ dihitung dengan menggunakan program POLO-PC.

Pada uji pengaruh residu, minyak tumbuhan disiapkan pada konsentrasi $0,1 \%, 0,5 \%, 1 \%, 3 \%$, dan $5 \%$. Kemudian $2 \mathrm{ml}$ larutan minyak dituangkan ke dalam cawan petri (diameter $9 \mathrm{~cm} \times$ tinggi $1,5 \mathrm{~cm}$ ) sampai seluruh permukaan cawan terbasahi. 
Selanjutnya, 10 ekor imago betina yang berumur kurang atau sama dengan 24 jam dimasukkan ke dalam cawan petri tersebut. Setiap perlakuan diulang 5 kali ulangan. Persentase kematian untuk tiap perlakuan dianalisis dengan sidik ragam dan diuji lanjutan dengan menggunakan Duncan's multiple range test pada taraf nyata $5 \%$.

\section{HASIL DAN PEMBAHASAN}

\section{Hasil}

Berdasarkan hasil pengujian enam jenis minyak dan serbuk tumbuhan baik pada pengujian penghambatan peneluran maupun mortalitas Callosobruchus sp. menunjukkan adanya pengaruh yang bervariasi.

\section{Pengaruh minyak dan serbuk tumbuhan terhadap peneluran Callosobruchus sp.}

Minyak E. aromatica dan C. citratus memberikan penghambatan peneluran yang baik, yaitu lebih dari $80 \%$, mulai konsentrasi 3\%, sementara minyak $V$. zizanioides memberikan penghambatan yang baik mulai konsentrasi $1 \%$. Minyak $P$. cablin hanya memberikan aktivitas penghambatan cukup baik, yaitu antara 70-80\%, mulai konsentrasi 3\%. Dua minyak lainnya, yaitu $F$. vulgare dan $\mathrm{R}$ communis menunjukkan hasil yang kurang baik (Tabel 1). Beberapa perlakuan memberikan nilai penghambatan peneluran negatif yang berarti bahwa jumlah telur yang diletakkan pada perlakuan lebih banyak daripada tanpa perlakuan.

Tabel 1. Persentase rata-rata penghambatan aktivitas peneluran Callosobruchus sp. yang diberi perlakuan minyak enam jenis tumbuhan pada beberapa tingkat konsentrasi

\begin{tabular}{lccccc}
\hline \hline \multirow{2}{*}{ Jenis minyak } & \multicolumn{5}{c}{ Rata-rata penghambatan peneluran $(\%) \pm \mathrm{SB}$ a } \\
\cline { 2 - 6 } & 0,1 & 0,5 & 1 & 3 & 5 \\
\hline E. aromatica & $9,6 \pm 31,7 \mathrm{a}$ & $-5,6 \pm 47,3 \mathrm{a}$ & $58,5 \pm 21,6 \mathrm{~b}$ & $89,0 \pm 8,2 \mathrm{~b}$ & $96,1 \pm 3,8 \mathrm{~b}$ \\
C. citratus & $12,9 \pm 9,2 \mathrm{a}$ & $5,9 \pm 26,0 \mathrm{a}$ & $-8,5 \pm 34,9 \mathrm{a}$ & $98,3 \pm 3,9 \mathrm{~b}$ & $99,3 \pm 0,9 \mathrm{~b}$ \\
P. cablin & $3,8 \pm 40,5 \mathrm{a}$ & $-8,8 \pm 67,9 \mathrm{a}$ & $-1,9 \pm 39,4 \mathrm{a}$ & $75,5 \pm 12,9 \mathrm{~b}$ & $79,2 \pm 21,1 \mathrm{~b}$ \\
V. zizanioides & $-50,6 \pm 66,9 \mathrm{a}$ & $32,4 \pm 18,1 \mathrm{~b}$ & $82,5 \pm 5,4 \mathrm{c}$ & $88,7 \pm 6,3 \mathrm{c}$ & $93,1 \pm 5,7 \mathrm{c}$ \\
F. vulgare & $-15,1 \pm 53,3 \mathrm{a}$ & $-9,9 \pm 85,4 \mathrm{a}$ & $-11,4 \pm 78,0 \mathrm{a}$ & $7,9 \pm 77,8 \mathrm{a}$ & $-14,3 \pm 82,4 \mathrm{a}$ \\
R. communis & $-25,7 \pm 86,4 \mathrm{a}$ & $-9,9 \pm 85,4 \mathrm{a}$ & $-32,5 \pm 60,5 \mathrm{a}$ & $-6,9 \pm 95,1 \mathrm{a}$ & $43,6 \pm 24,0 \mathrm{a}$ \\
\hline
\end{tabular}

a) $\mathrm{SB}=$ simpangan baku

Angka yang diikuti huruf yang sama pada baris yang sama menyatakan tidak berbeda nyata berdasarkan DMRT pada taraf uji 0,05. 
Tabel 2. Persentase rata-rata penghambatan aktivitas peneluran Callosobruchus sp. yang diberi perlakuan serbuk enam jenis tumbuhan pada beberapa perbandingan

\begin{tabular}{lccc}
\hline \hline \multirow{2}{*}{ Jenis serbuk } & \multicolumn{3}{c}{ Rata-rata penghambatan peneluran $(\%) \pm \mathrm{SB}$ a) } \\
\cline { 2 - 4 } & $1: 1$ & $1: 2$ & $1: 4$ \\
\hline E. aromatica & $100,0 \pm 0,0 \mathrm{a}$ & $99,8 \pm 0,5 \mathrm{a}$ & $96,6 \pm 5,8 \mathrm{a}$ \\
C. citratus & $-62,9 \pm 105,4 \mathrm{a}$ & $-75,6 \pm 150,5 \mathrm{a}$ & $-57,6 \pm 107,9 \mathrm{a}$ \\
P. cablin & $-48,8 \pm 56,1 \mathrm{a}$ & $-42,6 \pm 56,1 \mathrm{a}$ & $-11,2 \pm 23,6 \mathrm{a}$ \\
V. rizanioides & $-47,6 \pm 121,7 \mathrm{a}$ & $-85,7 \pm 147,6 \mathrm{a}$ & $-47,8 \pm 78,4 \mathrm{a}$ \\
F. vulgare & $-35,2 \pm 26,3 \mathrm{a}$ & $-31,2 \pm 32,2 \mathrm{a}$ & $-12,0 \pm 67,3 \mathrm{a}$ \\
R. communis & $-99,6 \pm 121,4 \mathrm{a}$ & $-12,9 \pm 42,2 \mathrm{a}$ & $-61,4 \pm 67,5 \mathrm{a}$ \\
\hline
\end{tabular}

a) $\mathrm{SB}=$ smpangan baku

Angka yang diikuti huruf yang sama pada baris yang sama menyatakan tidak berbeda nyata berdasarkan DMRT pada taraf uji 0,05.

Berbeda dengan perlakuan minyak, pada perlakuan dengan tepung tumbuhan tampak bahwa hanya tepung E. aromatica yang memberikan hasil baik untuk semua perbandingan. Lima jenis tepung tumbuhan lainnya tidak memberikan hasil yang baik (Tabel 2).

\section{Pengaruh minyak tumbuhan terhadap mortalitas Callosobruchus sp.}

Hasil pengujian dengan metode perlakuan setempat menunjukkan bahwa minyak E. aromatica menyebabkan mortalitas yang tinggi pada semua konsentrasi. Minyak E. aromatica pada dosis terendah ( $25 \mu \mathrm{g} /$ serangga $)$ sudah menghasilkan mortalitas hingga 82\% dan pada dosis $50 \mu \mathrm{g} /$ serangga menyebabkan mortalitas tertinggi yaitu 100\% pada 24 JSP, (Tabel 3). Minyak tumbuhan lain yang menyebabkan mortalitas tinggi adalah $V$. rizanioides yang pada dosis $25 \mu \mathrm{g} /$ serangga dan $50 \mu \mathrm{g} /$ serangga sudah mampu menyebabkan mortalitas lebih dari $90 \%$ pada 48 JSP, dan pada dosis 100 $\mu \mathrm{g} /$ serangga menyebabkan mortalitas 96\% sejak 24 JSP (Tabel 3).

Dua jenis minyak tumbuhan, $C$. citratus dan $P$. cablin, menyebabkan mortalitas tinggi jika diaplikasikan pada dosis $100 \mu \mathrm{g} / \mathrm{serangga}$. Perlakuan pada dosis lebih rendah dari $100 \mu \mathrm{g} /$ serangga menyebabkan mortalitas kurang dari 50\%, bahkan hingga pengamatan 72 JSP. Sementara itu, minyak F. vulgare hanya pada dosis 200 $\mu \mathrm{g} /$ serangga yang memberikan mortalitas tinggi yaitu 94\% sejak 24 JSP. Kemudian, minyak R. communis hingga dosis $200 \mu \mathrm{g} /$ serangga hanya menghasilkan mortalitas rata-rata 73,9\% (Tabel 3). 
Jika nilai $\mathrm{LD}_{50}$ dibandingkan, tampak bahwa minyak $V$. rizanioides tinggi yaitu $0,36 \mu \mathrm{g} /$ serangga dimenunjukkan toksisitas yang lebih bandingkan dengan minyak yang lain.

Tabel 3. Persentase rata-rata kematian Callosobruchus sp. yang diberi perlakuan minyak beberapa jenis tumbuhan dengan metode perlakuan setempat

\begin{tabular}{|c|c|c|c|c|}
\hline \multirow{2}{*}{ Jenis minyak } & \multirow{2}{*}{$\begin{array}{c}\text { Dosis } \\
(\mu g / \text { serangga })\end{array}$} & \multicolumn{3}{|c|}{ Mortalitas (\%) \pm SBa) } \\
\hline & & 24 jam & $48 \mathrm{jam}$ & 72 jam \\
\hline \multirow[t]{5}{*}{ E. aromatica } & 25 & $82,0 \pm 20,5 a$ & $82,0 \pm 20,5 a$ & $82,0 \pm 20,5 a$ \\
\hline & 50 & $100,0 \pm 0,0 \mathrm{a}$ & $100,0 \pm 0,0 \mathrm{a}$ & $100,0 \pm 0,0 \mathrm{a}$ \\
\hline & 100 & $100,0 \pm 0,0 \mathrm{a}$ & $100,0 \pm 0,0 \mathrm{a}$ & $100,0 \pm 0,0 \mathrm{a}$ \\
\hline & 150 & $100,0 \pm 0,0 \mathrm{a}$ & $100,0 \pm 0,0 \mathrm{a}$ & $100,0 \pm 0,0 \mathrm{a}$ \\
\hline & 200 & $100,0 \pm 0,0 \mathrm{a}$ & $100,0 \pm 0,0 \mathrm{a}$ & $100,0 \pm 0,0 \mathrm{a}$ \\
\hline \multirow[t]{5}{*}{ C. citratus } & 25 & $8,0 \pm 4,5 \mathrm{a}$ & $18,0 \pm 4,5 a$ & $25,9 \pm 5,5 a$ \\
\hline & 50 & $36,0 \pm 23,0 \mathrm{~b}$ & $38,0 \pm 19,2 b$ & $49,9 \pm 21,2 b$ \\
\hline & 100 & $100,0 \pm 0,0 \mathrm{c}$ & $100,0 \pm 0,0 \mathrm{c}$ & $100,0 \pm 0,0 \mathrm{c}$ \\
\hline & 150 & $98,0 \pm 4,5 \mathrm{c}$ & $100,0 \pm 0,0 \mathrm{c}$ & $100,0 \pm 0,0 \mathrm{c}$ \\
\hline & 200 & $100,0 \pm 0,0 \mathrm{c}$ & $100,0 \pm 0,0 \mathrm{c}$ & $100,0 \pm 0,0 \mathrm{c}$ \\
\hline \multirow[t]{5}{*}{ P. cablin } & 25 & $11,9 \pm 13,1 \mathrm{a}$ & $15,9 \pm 11,4 a$ & $19,9 \pm 12,3 \mathrm{a}$ \\
\hline & 50 & $37,9 \pm 17,9 b$ & $41,9 \pm 15,8 b$ & $49,9 \pm 15,8 b$ \\
\hline & 100 & $89,9 \pm 14,2 \mathrm{c}$ & $95,9 \pm 8,9 \mathrm{c}$ & $95,9 \pm 8,9 c$ \\
\hline & 150 & $93,9 \pm 5,5 c$ & $97,9 \pm 4,5 c$ & $97,9 \pm 4,5 c$ \\
\hline & 200 & $97,9 \pm 4,5 c$ & $97,9 \pm 4,5 c$ & $97,9 \pm 4,5 \mathrm{c}$ \\
\hline \multirow[t]{5}{*}{$V$. zizanioides } & 25 & $64,0 \pm 21,9 a$ & $92,0 \pm 13,0 \mathrm{a}$ & $95,9 \pm 5,5 a$ \\
\hline & 50 & $76,0 \pm 15,2 \mathrm{a}$ & $96,0 \pm 8,9 \mathrm{a}$ & $95,9 \pm 5,5 a$ \\
\hline & 100 & $96,0 \pm 5,5 b$ & $100,0 \pm 0,0 \mathrm{a}$ & $100,0 \pm 0,0 \mathrm{a}$ \\
\hline & 150 & $98,0 \pm 4,5 b$ & $100,0 \pm 0,0 \mathrm{a}$ & $100,0 \pm 0,0 \mathrm{a}$ \\
\hline & 200 & $100,0 \pm 0,0 \mathrm{~b}$ & $100,0 \pm 0,0 \mathrm{a}$ & $100,0 \pm 0,0 \mathrm{a}$ \\
\hline \multirow[t]{5}{*}{ F. vulgare } & 25 & $2,0 \pm 4,5 a$ & $12,0 \pm 8,4 \mathrm{a}$ & $12,0 \pm 8,4 a$ \\
\hline & 50 & $8,0 \pm 4,5 \mathrm{a}$ & $14,0 \pm 8,9 \mathrm{a}$ & $20,0 \pm 14,1 \mathrm{a}$ \\
\hline & 100 & $32,0 \pm 10,9 b$ & $38,0 \pm 14,8 b$ & $40,0 \pm 14,1 b$ \\
\hline & 150 & $50,0 \pm 10,0 \mathrm{c}$ & $58,0 \pm 8,4 c$ & $64,0 \pm 13,4 \mathrm{c}$ \\
\hline & 200 & $94,0 \pm 8,9 \mathrm{c}$ & $94,0 \pm 8,9 c$ & $94,0 \pm 8,9 \mathrm{c}$ \\
\hline \multirow[t]{5}{*}{ R. communis } & 25 & $-0,1 \pm 7,1 \mathrm{a}$ & $1,9 \pm 8,4 \mathrm{a}$ & $11,9 \pm 13,0 \mathrm{a}$ \\
\hline & 50 & $11,9 \pm 23,9 \mathrm{a}$ & $23,9 \pm 16,8 \mathrm{a}$ & $29,9 \pm 14,1 \mathrm{a}$ \\
\hline & 100 & $49,9 \pm 31,7 b$ & $51,9 \pm 28,6 b$ & $55,9 \pm 25,1 b$ \\
\hline & 150 & $65,9 \pm 11,4 b$ & $67,9 \pm 8,4 b$ & $67,9 \pm 4,5 b$ \\
\hline & 200 & $69,9 \pm 18,7 b$ & $73,9 \pm 11,4 b$ & $71,9 \pm 19,3 b$ \\
\hline
\end{tabular}

a) $\mathrm{SB}=$ simpangan baku

Angka yang diikuti huruf yang sama pada kolom yang sama untuk setiap jenis minyak tumbuhan menyatakan tidak berbeda nyata berdasarkan DMRT pada taraf uji 0,05 
Tabel 4. Nilai $\mathrm{LD}_{50}$ dan $\mathrm{LD}_{95}$ dan persamaan regresi probit minyak enam jenis tumbuhan dengan metode perlakuan setempat

\begin{tabular}{lccccc}
\hline \hline \multirow{2}{*}{ Jenis minyak } & $\mathrm{LD}_{50}$ & $\mathrm{LD}_{95}$ & & \multicolumn{2}{c}{ Persamaan regresi $(\mathrm{y}=\mathrm{a}+\mathrm{bx})$} \\
\cline { 2 - 3 } \cline { 5 - 5 } E. aromatica & $(\mu \mathrm{g} /$ serangga $)$ & $(\mu \mathrm{g} /$ serangga $)$ & & $\mathrm{a}$ & $\mathrm{b}$ \\
V. rizanioides & 1,78 & 2,19 & & $-4,58$ & 18,25 \\
C. citratus & 0,36 & 3,0 & & 0,79 & 1,78 \\
P. cablin & 4,34 & 11,77 & $-2,42$ & 3,80 \\
R. communis & 4,65 & 10,19 & $-3,23$ & 4,83 \\
F. vulgare & 9,43 & 43,45 & $-2,42$ & 2,48 \\
\hline
\end{tabular}

Sementara itu, jika nilai $\mathrm{LD}_{95}$ dibandingkan, ternyata minyak $E$. aromatica menunjukkan toksisitas yang lebih baik yaitu $2,19 \mu \mathrm{g} /$ serangga yang diikuti oleh minyak $V$. zizanioides yaitu 3,0 $\mu \mathrm{g} /$ serangga (Tabel 4). Kenaikan sedikit dosis uji memberikan respon mortalitas lebih tinggi pada pengujian dengan minyak E. aromatica dibandingkan dengan $V$. rizanioides. Sementara dengan empat jenis minyak lainnya, toksisitas minyak $P$. cablin hampir sama dengan minyak $C$. citratus dan toksisitas minyak $F$. vulgare hampir sama dengan toksisitas minyak $R$. communis.

Perlakuan dengan metode residu menunjukkan bahwa hanya satu jenis minyak, yaitu $V$. rizanioides pada konsentrasi terendah $(0,1 \%)$ yang menyebabkan aktivitas mortalitas tinggi yaitu $88 \%$ pada 72 JSP. Perlakuan dengan konsentrasi lebih tinggi menghasilkan persentase rata-rata mortalitas 100\% sejak 24 JSP. Empat jenis minyak, E. aromatica, C. citratus, $P$. cablin, dan $\mathrm{R}$. communis memberikan persentase rata-rata mortalitas yang tinggi, yaitu antara $90-100 \%$ pada perlakuan dengan konsentrasi 3\% atau lebih. Perlakuan dengan minyak F. vulgare hingga konsentrasi tertinggi (5\%) hanya memberikan persentase rata-rata mortalitas yang rendah, yaitu kurang dari 60\% (Tabel 5).

\section{Pembahasan}

Berdasarkan hasil pengujian yang dilakukan, beberapa bahan uji baik berupa serbuk maupun minyak tumbuhan memberikan pengaruh pada peneluran dan mortalitas Callosobruchus sp. yang bervariasi. Pada perlakuan serbuk tanaman, hanya tepung E. aromatica yang menunjukkan penghambatan aktivitas peneluran yang baik dengan rata-rata penghambatan di atas $90 \%$ pada semua perbandingan (1:1, 1:2, dan 1:4). Tepung tumbuhan lainnya kurang berpengaruh terhadap peneluran, bahkan perlakuan beberapa jenis serbuk justru meningkatkan peletakan telur. 
Tabel 5. Persentase rata-rata kematian Callosobruchus sp. yang diberi perlakuan minyak beberapa jenis tumbuhan dengan metode perlakuan setempat

\begin{tabular}{|c|c|c|c|c|}
\hline \multirow{2}{*}{ Jenis minyak } & \multirow{2}{*}{$\begin{array}{c}\text { Dosis } \\
(\mu \mathrm{g} / \text { serangga })\end{array}$} & \multicolumn{3}{|c|}{ Mortalitas $\left.(\%) \pm \mathrm{SB}^{\mathrm{a}}\right)$} \\
\hline & & 24 jam & 48 jam & $72 \mathrm{jam}$ \\
\hline \multirow[t]{5}{*}{ E. aromatica } & 25 & $0,0 \pm 0,0 \mathrm{a}$ & $0,0 \pm 0,0 \mathrm{a}$ & $-2,2 \pm 4,9 a$ \\
\hline & 50 & $0,0 \pm 0,0 \mathrm{~b}$ & $0,0 \pm 0,0 \mathrm{~b}$ & $-0,2 \pm 7,5 \mathrm{a}$ \\
\hline & 100 & $0,0 \pm 0,0 \mathrm{c}$ & $0,0 \pm 0,0 \mathrm{ac}$ & $-2,2 \pm 4,9 \mathrm{a}$ \\
\hline & 150 & $100,0 \pm 0,0 \mathrm{~d}$ & $100,0 \pm 0,0 \mathrm{~d}$ & $100,0 \pm 0,0 \mathrm{~b}$ \\
\hline & 200 & $100,0 \pm 0,0 \mathrm{e}$ & $100,0 \pm 0,0 \mathrm{e}$ & $100,0 \pm 0,0 \mathrm{~b}$ \\
\hline \multirow[t]{5}{*}{ C. citratus } & 25 & $0,0 \pm 0,0 \mathrm{a}$ & $-3,7 \pm 14,6 a$ & $-8,9 \pm 18,8 a$ \\
\hline & 50 & $0,0 \pm 4,5 \mathrm{a}$ & $-2,6 \pm 23,9 a$ & $-7,6 \pm 7,0 \mathrm{a}$ \\
\hline & 100 & $34,0 \pm 36,5 b$ & $62,9 \pm 46,5 b$ & $79,3 \pm 32,8 b$ \\
\hline & 150 & $100,0 \pm 0,0 \mathrm{c}$ & $100,0 \pm 0,0 \mathrm{c}$ & $100,0 \pm 0,0 \mathrm{~b}$ \\
\hline & 200 & $100,0 \pm 0,0 \mathrm{c}$ & $100,0 \pm 0,0 \mathrm{c}$ & $100,0 \pm 0,0 \mathrm{~b}$ \\
\hline \multirow[t]{5}{*}{ P. cablin } & 25 & $6,0 \pm 8,9 \mathrm{a}$ & $8,0 \pm 8,4 a$ & $15,9 \pm 13,4 a$ \\
\hline & 50 & $2,0 \pm 4,5 a$ & $12,0 \pm 16,4 \mathrm{ab}$ & $27,9 \pm 17,9 \mathrm{ab}$ \\
\hline & 100 & $10,0 \pm 10,0 \mathrm{a}$ & $28,8 \pm 22,8 b$ & $43,9 \pm 36,5$ \\
\hline & 150 & $62,0 \pm 35,6 b$ & $92,0 \pm 13,0 \mathrm{c}$ & $93,9 \pm 5,5 c$ \\
\hline & 200 & $100,0 \pm 0,0 \mathrm{c}$ & $100,0 \pm 0,0 \mathrm{c}$ & $97,9 \pm 4,5 c$ \\
\hline \multirow[t]{5}{*}{$V$. zizanioides } & 25 & $42,0 \pm 24,9 a$ & $76,0 \pm 23,0 \mathrm{a}$ & $88,0 \pm 42,0 \mathrm{a}$ \\
\hline & 50 & $100,0 \pm 0,0 \mathrm{~b}$ & $100,0 \pm 0,0 \mathrm{~b}$ & $100,0 \pm 0,0 \mathrm{~b}$ \\
\hline & 100 & $100,0 \pm 0,0 \mathrm{~b}$ & $100,0 \pm 0,0 \mathrm{~b}$ & $100,0 \pm 0,0 \mathrm{~b}$ \\
\hline & 150 & $100,0 \pm 0,0 b$ & $100,0 \pm 0,0 \mathrm{~b}$ & $100,0 \pm 0,0 \mathrm{~b}$ \\
\hline & 200 & $100,0 \pm 0,0 \mathrm{~b}$ & $100,0 \pm 0,0 \mathrm{~b}$ & $100,0 \pm 0,0 \mathrm{~b}$ \\
\hline \multirow[t]{5}{*}{ F. vulgare } & 25 & $0,0 \pm 0,0 \mathrm{a}$ & $-2,2 \pm 4,9 a$ & $0,6 \pm 23,3 a$ \\
\hline & 50 & $4,0 \pm 5,5 a$ & $3,8 \pm 9,4 \mathrm{a}$ & $11,9 \pm 28,4 a$ \\
\hline & 100 & $6,0 \pm 8,9 a$ & $5,8 \pm 11,8 \mathrm{a}$ & $12,0 \pm 18,2 \mathrm{a}$ \\
\hline & 150 & $12,0 \pm 13,0 \mathrm{a}$ & $18,2 \pm 16,3 a$ & $33,8 \pm 32,2 \mathrm{a}$ \\
\hline & 200 & $36,0 \pm 36,5 b$ & $52,7 \pm 30,6 b$ & $59,9 \pm 31,4 b$ \\
\hline \multirow[t]{5}{*}{ R. communis } & 25 & $6,0 \pm 5,5 a$ & $4,0 \pm 5,5 a$ & $3,5 \pm 12,2 \mathrm{a}$ \\
\hline & 50 & $0,0 \pm 0,0 \mathrm{a}$ & $-2,2 \pm 4,9 \mathrm{a}$ & $3,5 \pm 12,2 \mathrm{a}$ \\
\hline & 100 & $38,0 \pm 39,6 b$ & $45,8 \pm 47,6 b$ & $53,9 \pm 51,4 b$ \\
\hline & 150 & $100,0 \pm 0,0 \mathrm{c}$ & $100,0 \pm 0,0 \mathrm{c}$ & $100,0 \pm 0,0 \mathrm{c}$ \\
\hline & 200 & $100,0 \pm 0,0 \mathrm{c}$ & $100,0 \pm 0,0 \mathrm{c}$ & $100,0 \pm 0,0 \mathrm{c}$ \\
\hline
\end{tabular}

a) $\mathrm{SB}=$ Simpangan baku

Angka yang diikuti huruf yang sama pada kolom yang sama untuk setiap jenis minyak tumbuhan menyatakan tidak berbeda nyata berdasarkan DMRT pada taraf uji 0,05

Hal ini mungkin disebabkan oleh adanya senyawa tertentu yang memiliki sifat atraktan pada konsentrasi rendah, tetapi pada konsentrasi yang lebih tinggi berfungsi sebagai penolak atau penghambat aktivitas peneluran maupun penghambat aktivitas makan (Mc Indoo 1983 dalam Prakash \& Rao 1997). Adanya aktivitas penghambatan peneluran oleh serbuk E. aromatica 
membuka peluang untuk memanfaatkan tepung ini sebagai agen pengendalian hama gudang yang mungkin dapat dilakukan dengan cara mencampur bahan yang akan disimpan dengan tepung $E$. aromatica atau menaburi permukaan karung dengan serbuk tersebut. Mengenai hal ini perlu dilakukan penelitian lebih lanjut untuk mengetahui potensi dan keefektivannya pada skala gudang.

Jenis minyak yang efektif dalam memberikan penghambatan peneluran adalah minyak $V$. rizanioides. Minyak lain, yaitu E. aromatica, P. cablin, dan C. citratus juga mampu memberikan perlindungan yang baik pada konsentrasi yang lebih tinggi. Tentunya dalam pemilihan potensi sebagai agen pengendalian, agen dengan efikasi baik pada konsentrasi lebih rendah mempunyai peluang yang lebih besar untuk dikembangkan karena berhubungan dengan penyediaan agen dan juga aspek ekonomi. Kemungkinan yang bisa dikembangkan juga ialah melalui pencampuran beberapa bahan tumbuhan, namun hal ini perlu dilakukan pengujian terlebih dahulu untuk mengetahui efikasinya. Mengingat ketersediaannya di pasar cukup melimpah dengan harga yang tidak terlalu mahal, pemanfaatan minyak tumbuhan sebagai agen pengendalian hama gudang cukup menjanjikan.

Minyak tumbuhan yang efektif menyebabkan mortalitas tinggi dengan metode perlakuan setempat adalah mi- nyak E. aromatica dan $V$. rizanioides yang pada dosis $50 \mu \mathrm{g} /$ serangga sudah mampu menyebabkan kematian di atas $80 \%$ dan pada dosis yang lebih tinggi mampu menyebabkan kematian hingga 100\%. Minyak V. rizanioides juga memberikan efek mortalitas yang baik dengan uji residu. Pada konsentrasi terendah, yaitu $0,1 \%$, minyak jenis ini memberikan rata-rata mortalitas 88\% pada 72 JSP bahkan mencapai $100 \%$ pada konsentrasi yang lebih tinggi.

Berdasarkan hubungan antara dosis dan mortalitas serangga, minyak $V$. zizanioides memiliki nilai $\mathrm{LD}_{50}$ terendah, sedang minyak E. aromatica memiliki nilai $\mathrm{LD}_{95}$ terendah. Pada $\mathrm{LD}_{50}$ minyak $V$. rizanioides memiliki efek toksisitas yang lebih tinggi dibandingkan dengan minyak tumbuhan lainnya, sedang pada $\mathrm{LD}_{95}$ minyak E. aromatica memiliki efek toksisitas yang lebih tinggi dibandingkan dengan minyak tumbuhan lainnya. Dapat dinyatakan bahwa minyak E. aromatica memiliki efikasi yang lebih baik dibandingkan dengan minyak $V$. zizanioides, karena minyak E. aromatica memberikan efek mortalitas 95\% hanya dengan meningkatkan sedikit dosis, sedang untuk minyak $V$. zizanioides harus menaikkan dosis yang lebih tinggi untuk mendapatkan mortalitas $95 \%$.

Mekanisme penghambatan peneluran dan mortalitas dari minyak dan serbuk tumbuhan yang digunakan dipengaruhi oleh adanya senyawa- 
senyawa metabolit sekunder yang terkandung dalam bahan tumbuhan tersebut. Senyawa-senyawa aktif seperti eugenol yang terkandung di dalam $E$. aromatica, $\beta$-patchoulen dan fraksinasi alkohol dalam $P$. cablin, serta nootkaton dalam $V$. rizanioides dapat mengganggu fisiologi dan perilaku Callosobruchus sp. apabila serbuk atau minyak tumbuhan tersebut diaplikasikan. Minyak tumbuhan dapat mengganggu proses bertelur dan perkembangan Callosobruchus sp. pada kacang hijau dan kacang adzuki, bahkan dapat menyebabkan kematian (Edwards et al. 1980 dalam Wibowo 2003). Ohsawa \& Dadang (1998) menyatakan bahwa senyawa aktif yang terkandung dalam minyak $V$. rizanioides dapat berperan sebagai insektisida. Senyawa-senyawa aktif tersebut antara lain $\beta$-vetivenen, $\gamma$ vetivenen, vetivenol, $\alpha$-vetivenon, $\beta$ vetivenon dan nootkaton. Ekstrak $V$. zizanioides memiliki aktivitas repelen yang tinggi terhadap kumbang jagung Sitophilus zeamais (Coleoptera: Curculionidae) pada dosis 0,05 $\mu \mathrm{g} /$ serangga (Maistrello et al. 2001).

Ekstrak tanaman $P$. cablin yang efektif dalam mempengaruhi aktivitas biologi Callosobruchus sp. adalah ekstrak metanol (Wibowo 2003). Ohsawa and Dadang (1998) melaporkan bahwa minyak $P$. cablin mengandung senyawa aktif yang dapat berperan sebagai insektisida. Lebih lanjut dilaporkan bahwa senyawa aktif $\beta$-patchoulen dan fraksinasi alkohol dari $P$. cablin pada dosis 0,5 $\mu \mathrm{g} /$ serangga dapat mempengaruhi proses biologi Aedes aegypti (Diptera: Culicidae). Kataren (1985) menyatakan bahwa minyak E. aromatica mengandung eugenol dan eugenol asetat. Eugenol merupakan persenyawaan yang paling penting di dalam minyak E. aromatica yang kandungannya dapat mencapai 70-93\%.

Minyak C. citratus mengandung bahan aktif atsiri yang terdiri dari senyawa sintral, sitronela, geraniol, mirsena, nerol, farnesol, metil heptenon dan dipentena, dan dapat berfungsi sebagai insektisida dan fungisida (Kardinan 2002).

Secara umum dapat dinyatakan bahwa minyak dan serbuk tumbuhan dapat digunakan sebagai alternatif untuk mendapatkan senyawa-senyawa alami yang dapat menekan hama sasaran. Berdasarkan pengujian, beberapa bahan uji seperti serbuk dan minyak E. aromatica terbukti cukup efektif dan dari sisi ekonomi lebih murah, efisien dan ramah lingkungan.

\section{KESIMPULAN}

Beberapa bahan tumbuhan menunjukkan keefektivan yang tinggi dalam mempengaruhi aktivitas biologi Callosobruchus sp. Serbuk E. aromatica dan minyak $V$. rizanioides memberikan rata-rata penghambatan aktivitas peneluran yang baik, sementara minyak E. aromatica dan $V$. rizanioides memberikan persentase rata-rata mortalitas yang tinggi. 
Dadang et al.,: Aktivitas Minyak dan Serbuk Enam Spesies Tumbuhan.

\section{DAFTAR PUSTAKA}

Kardinan A. 2002. Pestisida Nabati: Ramuan dan Aplikasi. Jakarta: Penebar Swadaya..

Kataren S. 1985. Pengantar Teknologi Minyak. Atsiri. Terjemahan A. Saptorahardjo. Jakarta: Balai Pustaka.

Maistrello L, Henderson G, Laine RA. 2001. Efficacy of vetiver oil and nootkatone as soil bariers against Formosan subteranean termite (Isoptera: Rhinotermitidae). J Econ Entomol 94 (6): 1532-1537.

Ohsawa K, Dadang. 1998. Searching for substances from tropical plants and their biological activities to insects. I House and Household Insect Pests 20 (1): 31-46.

Prakash A, Rao J. 1997. Botanical Pesticides in Agriculture. Florida. CRC Press.

Priyono A. 1987. Pengaruh tepung daun mimba (Azadirachta indica A. Juss), daun mimbi (Melia azedarach L.) dan daun pandan wangi (Pandanus amaryllifolius Roxb) terhadap investasi hama Callosobruchus chinensis L. (Coleoptera: Bruchidae) pada biji kacang hijau (Phaseolus radiatus L.). [skripsi]. Bogor: Jurusan Hama dan Penyakit Tumbuhan, Institut Pertanian Bogor.

Suprapto HS, Sutarman T. 1982. Bertanam kacang hijau. Jakarta: Penebar Swadaya.

Tauthong P, Wanleelag. 1978. Studies on the life history of southern cowpea weevil (Callosobruchus chinensis L.) and it's control in pest of stored product. BIOTROP special publication. BIOTROP SEAMEO Regional center for Tropical Biology. Bogor. April 24-26.

Wibowo H. 2003. Aktivitas biologi tujuh ekstrak tanaman terhadap Callosobruchus sp. (Coleoptera: Bruchidae). [skripsi]. Bogor: Jurusan Hama dan Penyakit Tumbuhan, Institut Pertanian Bogor. 